\title{
A PoEsia COMO ARMA DE COMBATE: UM ESTUdO SOBRE A REAPROPRIAÇÃO DE SENTIDOS EM UMA CANTIGA MEDIEVAL-IBÉRICA (SÉCULO XIII)
}

\author{
Poetry as a combat weapon: a study on the \\ reappropriation of meanings through an Iberian- \\ medieval song (XIII century)
}

\author{
José D’Assunção Barros*
}

\section{RESUMO}

O objeto deste artigo é discutir, a partir da análise de uma cantiga medieval ibérica específica, as relações entre Poesia e Poder que podem ser entrevistas no exame das tensões políticas e sociais das sociedades medievais ibéricas que transparecem na prática e na poesia dos trovadores galego-portugueses. Depois de uma apresentação inicial do contexto histórico e das fontes examinadas, o texto analisa uma cantiga galego-portuguesa na qual pode ser vista uma pluralidade de sentidos de acordo com os deslocamentos da cantiga no contexto social e político. O acontecimento examinado através da análise da cantiga é a centralização monárquica a que assistimos em Portugal do século XIII.

Palavras-chave: Poesia e Poder; trovadores medievais; tensões sociais; sentido; acontecimento político.

* Universidade Federal Rural do Rio de Janeiro. 


\begin{abstract}
The subject of this article is to discuss, through the analysis of a specific Iberian medieval song, the relations between Poetry and Power by the examination of political and social tensions that appear in medieval Iberian societies which are reflected in poetry and other practices of the Galician Portuguese troubadours. Besides an initial presentation of the historical context and the sources examined, the text analyses a galician-portuguese chant in which we can see a plurality of senses according to the movements of the chant in the political and social context. The case studied is the monarchic centralization in Portugal in the XIII century.
\end{abstract}

Keywords: Poetry and Power, Medieval troubadours; socials tensions, sense, political event.

A Idade Média tem se mostrado um período extremamente rico no que se refere ao estudo da utilização da poesia como veículo para a crítica social e política. Se a poesia amorosa e idílica dos trovadores medievais imortalizou-se por ter trazido à tona uma nova forma de amar conhecida pelo nome de Amor Cortês, e considerando que suas canções de amor até hoje encantam inúmeros apreciadores através de uma magnífica e singular combinação de poesia e música já merecedora de incontáveis gravações de musicistas interessados na música antiga, não deve ser esquecida a mordaz poesia satírica também encaminhada pelos mesmos trovadores em lugares como França, Itália, Europa Central e, por fim, a península Ibérica - objeto deste artigo.

A cantiga a ser analisada neste artigo refere-se ao grupo dos chamados "trovadores galego-portugueses". Atuantes na parte ocidental da península ibérica (Portugal, Galícia, Leão e Castela), estes trovadores são assim chamados por terem adotado como idioma poético em comum o Galego-Português. Unidos por este idioma e por uma série de práticas poéticas em comum, esses poetas-cantores dos séculos XIII e XIV podiam ser vistos principalmente no Ocidente Ibérico em ambientes diversos que iam das tavernas e da praça pública às cortes régias e senhoriais.

Quando nos aproximamos do trovadorismo ibérico da Idade Média, o primeiro problema a se destacar é a percepção de que, à parte a "cor da época" em comum, há certas nuanças a contrastarem o trovadorismo peninsular em relação aos demais trovadorismos europeus. Por exemplo, se 
dentro de sua sociedade rigidamente hierarquizada o trovadorismo sempre foi espaço de relativa diversidade, com cada tipo social tendo direito a expressar sua voz, é no trovadorismo ibérico - mais do que em seus congêneres europeus - que estes vários tipos sociais são postos a duelar liricamente de forma bastante significativa. Não por acaso aí florescem amplamente as "tenções". Este gênero que tradicionalmente opunha um trovador a outro em uma competição lírica - também presente no restante da Europa - assume na poesia ibérica a forma de um verdadeiro confronto de tipos sociais, onde o jogral mais humilde tem espaço para enfrentar o mais poderoso dos nobres. Também não é a toa que na poesia medieval ibérica as canções satíricas ganham especial relevo, deixando à mostra todas as tensões sociais presentes naquela sociedade.

Existem, portanto, nuanças contrastantes que parecem diferenciar do restante europeu o repertório poético dos trovadores galego-portugueses. Correspondem estas nuanças a contrastes entre as sociedades ibéricas e as demais sociedades europeias do mesmo período? o que diferenciaria o contexto político e cultural de Portugal e Castela em relação às outras regiões europeias, de modo a nelas produzir um canto de sonoridades tão diversas? Em contrapartida, já que também existem ligações importantes entre o circuito trovadoresco ibérico e os demais circuitos trovadorescos da Europa, que substrato comum uniria o nosso lirismo às diversas sociedades trovadorescas medievais?

Uma suspeita pôde facilmente se converter em hipótese. Os reinos ibéricos de Portugal e Castela, como se sabe, anteciparam-se na Idade Média Central (já no século XIII) a um processo político que mais tarde seria o de cada país europeu. Referimo-nos ao processo centralizador que logo culminaria com a formação dos estados nacionais a partir do século XV. A descentralização feudal lentamente cedia espaço a uma nova estruturação política - esta cada vez mais centralizada em torno da figura do monarca. Este processo ocorreu no entrechoque de duas orientações antagônicas: o interesse de parte da nobreza em conservar a autonomia senhorial e o projeto centralizador das novas monarquias. Processo, aliás, de avanços e retrocessos entre uma orientação e outra - e que, além disso, trazia complexidades adicionais: o próprio monarca era a seu modo uma figura ambígua, por vezes mergulhado na mentalidade feudal e tratando o reino como um imenso senhorio, e por outras prenunciando um novo tempo.

Esse momento centralizador muito específico também traz na crista de sua onda um tipo de rei muito singular. Trata-se de um rei especialmente interessado na cultura - e estamos falando aqui tanto de Portugal como de Castela no mesmo período: um rei sábio, ele mesmo artista, e algumas vezes também um trovador (como Afonso X de Castela e D. Dinis de Portugal). 
Sobretudo, são reis que aprendem e sabem lidar com a alteridade e com a diversidade: no plano externo, dialogam com a cultura islâmica de sua época, mesmo que no momento oportuno saibam se projetar imaginariamente como os grandes líderes da Reconquista; no plano interno, tornam-se os próprios artífices de uma figura do rei como mediador privilegiado de todas as classes sociais. Pretendem erigir as suas cortes como grandes espaços de cultura, e nos seus saraus trovadorescos abrem as portas do Paço para a diversidade social através da inclusão de trovadores que vão do mais humilde jogral até o mais abastado dos nobres ${ }^{1}$.

Estes reis mediadores e sábios, poder-se-ia dizer, divertem-se (e instruem-se) ao assistirem nas suas cortes ao espetáculo social e político através da arte trovadoresca. $O$ trovadorismo ibérico é de muitas maneiras produto deste "embate centralizador", anunciador dos novos tempos que breve desembocariam na modernidade, e que já vemos se esboçar no ocidente ibérico do século XIII com o concomitante processo de aperfeiçoamento das instituições monárquicas - este último só se iniciando no restante da Europa um pouco depois. Além disto, estamos em um momento muito específico da Reconquista, a partir do qual emerge uma sociedade algo distinta, por exemplo, do feudalismo francês. Por isso mesmo tem-se um trovadorismo português e castelhano em parte distinto do trovadorismo das cortes provençais, berços do amor cortês e da poesia trovadoresca medieval. É este trovadorismo ocidental-ibérico que, trazido para dentro da corte como parte das estratégias culturais do monarca e aqui examinado a partir de uma cantiga, torna-se o nosso objeto de estudo ${ }^{2}$.

Nosso acontecimento é, portanto o momento trovadoresco ibérico a partir do instante em que ele é perturbado de maneira mais incisiva pela apropriação por parte do monarca centralizador, pelas forças sociais que resistem ao seu projeto e por outras trazidas a reboque da pluralidade que adentra a corte. Momento, portanto, em que o trovadorismo da corte régia

1 A palavra "trovador" era nas cortes trovadorescas de Portugal e Castela um grande objeto de disputas. Os trovadores-fidalgos reivindicavam que esta expressão só poderia ser empregada para os poetas-cantores de origem nobre, aos demais sendo reservadas as designações de "jograis" e "segréis". Alguns dos jograis mais criativos do trovadorismo galego-português, contudo, reivindicavam através de suas cantigas a possibilidade de serem chamados de trovadores, o que para os trovadores-fidalgos era uma impertinência e uma intromissão na designação que deveria lhes ser reservada. Estas disputas no interior da palavra "trovador" encerram confrontos em uma verdadeira arena social. Por outro lado, estaremos utilizando neste artigo a palavra "trovador" no sentido amplo, em referência a todos os poetas-cantores que participavam do trovadorismo galego-português.

2 A expressão "trovadorismo português e castelhano" é aqui mera referência às cortes que dinamizam este movimento. Habitualmente utiliza-se para este circuito trovadoresco que prospera no ocidente-ibérico - isto é, nos reinos de Portugal e Castela - a denominação de "trovadorismo galego-português", em função do já mencionado fato de que o idioma utilizado nesta produção poética era o Galego-Português. 
torna-se explicitamente uma "arena" onde se entrechocam várias forças e elementos sociais, à parte o "diálogo de culturas" que já tinha sua ressonância na poesia trovadoresca.

"Acontecimento", como se vê, é tomado aqui não no sentido tradicional de uma decisão, um tratado, uma batalha, mas no de uma relação de forças que se inverte, de um poder que é apropriado, de um vocabulário que é retomado contra seus utilizadores, de uma dominação que se enfraquece diante de outra que faz a sua entrada ${ }^{3}$. Acontecimento-processo.

Limitando o poder senhorial, o projeto centralizador incide de maneira pluridiversificada no plano da cultura e interfere até na própria poesia aristocrática. $\mathrm{O}$ acontecimento se dá em momentos aproximados em cada um destes pólos: em Castela no final do reinado de Fernando III, mas, sobretudo com Afonso X; em Portugal a partir da instalação de um novo ramo da dinastia de Borgonha com D. Afonso III e até D. Dinis e D. Afonso IV. Depois, novamente a relação de forças se inverte e, coincidentemente, o movimento trovadoresco ibérico se esvazia.

o "acontecimento" da "arena trovadoresca" nos conduz a um recorte cronológico entre 1250 a 1340 , referente a uma espacialidade constituída entre Portugal e Castela, estes dois pólos do movimento trovadoresco galego-português. Por opção, nos concentramos preferencialmente na segunda metade do século XIII, momento de maior efervescência da pluralidade trovadoresca. Durante este período desenrola-se, para além do já mencionado acirramento do "embate centralizador", um período crítico no embate entre os poderes régio e o poder papal. Como se não fosse tanto, desenvolve-se uma verdadeira "guerra de representações" entre cristãos e árabes neste período de menor atividade bélica da Reconquista. Momento de consolidação das instituições monárquicas, a sociedade ibérica daí emergente pode contemplar a sua riqueza de tensões internas - como, por exemplo, a projeção social dos cavaleiros vilãos intrometendo-se em espaços tradicionais da nobreza, ou ainda a crise de um setor da aristocracia empobrecido e a perambular na fronteira dos estamentos. Portanto, tensões sociais de toda a ordem vêm se juntar àquelas produzidas pelo encontro de culturas que tem lugar no anfiteatro ibérico. É esse grande concerto de forças sócio-culturais (concertare = disputar) que ressoa na música e na poesia medieval peninsular.

Eis então que o "paço trovadoresco" emerge como a "gota d' água" através da qual pretendemos enxergar algo do oceano inteiro. Afinal, não 
só o ambiente trovadoresco do Paço é "da mesma água" que a sociedade que o envolve, como contém vários dos tipos de "microorganismos" do oceano social que o circunda. O paço trovadoresco, para deixar mais claro, é por vezes uma micro-sociedade onde quase todos os discursos sociais se fazem presentes. Outras vezes, é também uma sociedade invertida, onde o que está embaixo tem a oportunidade de ficar em cima; e em um terceiro caso pode também se apresentar como uma sociedade imaginária. Por isso, são muitos os oceanos ocultos na substância desta gota d'água cuidadosamente escolhida.

As fontes históricas onde iremos recolher essa gota d'água que era a poesia das cortes trovadorescas também são bem peculiares. O cancioneiro galego-português, registro da poesia ibérica que circulava oralmente entre os séculos XIII e XIV ${ }^{4}$, desdobra-se na verdade em três documentos principais. São eles o Cancioneiro da Ajuda, o Cancioneiro da Vaticana e o Cancioneiro da Biblioteca Nacional.

Cada um destes documentos corresponde a uma grande coletânea da poesia trovadoresca ibérica que, à sua época, circulava sobretudo nas cortes régias de Portugal e Castela. Não representa, portanto, toda a produção dos poetas-cantores galego-portugueses, mas um recorte que se refere àqueles "paços trovadorescos" (isto é, ambientes trovadorescos das cortes régias). Por outro lado, também não representa toda a poesia trovadoresca das cortes régias, mas apenas aquela parte que se decidiu compilar por escrito - o que por si só já nos coloca perante problemas de filtragem a serem considerados. Em todo o caso, é uma poesia bastante representativa da poesia trovadoresca ibérica, conforme teremos oportunidade de verificar.

Algumas das cantigas trovadorescas galego-portuguesas aparecem em um e outro destes cancioneiros, às vezes em apenas um deles, de sorte que - para se contar com todo este conjunto denominado "cancioneiro galego-português" - é preciso contar com os três conjuntos documentais. Os manuscritos encontram-se atualmente nas bibliotecas que lhes emprestam seus nomes (Biblioteca da Ajuda, Biblioteca da Vaticana, Biblioteca Nacional). o primeiro deles - o Cancioneiro da Ajuda - foi compilado entre a última metade do século XIII e as primeiras décadas do século XIV, portanto no próprio período do trovadorismo galego-português. Quanto aos outros dois, embora

4 Algumas das cantigas registradas nos cancioneiros, mais particularmente as cantigas de amigo paralelísticas, possivelmente remontam a uma tradição de oralidade anterior. De qualquer forma, estas cantigas também tinham plena circularidade no período aqui considerado, e diversos dos trovadores deste período também foram autores de inúmeras cantigas de amigo - como foi, aliás, o caso do rei Dom Dinis. 
compilados em período posterior na Itália, consta que ambos teriam tido por fonte comum um certo Livro de Cantigas do Conde Dom Pedro, o qual foi posto por escrito na primeira metade do século XIV e depois desapareceu ${ }^{5}$.

O nosso objetivo neste artigo será o de nos aproximarmos da poesia trovadoresca de fundo político, que se relaciona mais diretamente com os problemas decorrentes do processo de centralização monárquica, através de uma única cantiga. Uma pesquisa sistemática das fontes poético-musicais galego-portuguesas tem nos trazido à tona toda uma série de tensões políticas e sociais que permitem elaborar um singular retrato da sociedade medieval ibérica deste período. Neste momento - para atender aos limites a que nos impusemos neste artigo - examinaremos uma cantiga específica. Nosso objetivo principal será precisamente o de mostrar a pluralidade de sentidos que podem atravessar uma cantiga conforme ela se desloque no espaço social e político e ao mesmo tempo os modos como esta cantiga pode ser constituída e se relacionar com um determinado acontecimento político. A cantiga será abordada aqui como uma chave para a compreensão da sociedade que a engendrou. Será vista como uma arma de guerra que podia ser empunhada pelos trovadores ibéricos que desejavam encaminhar suas críticas sociais e interferir no mundo político.

Para iniciarmos este trabalho, será oportuno desenvolvermos uma reflexão sobre o que é propriamente uma "cantiga", com relação às possibilidades de expressar e comunicar conteúdos sociais e políticos.

Começaremos por dizer que uma cantiga, independentemente das intenções de seu autor, pode conter uma pluralidade de sentidos. Para que um novo sentido se desprenda é por vezes bastante que a desloquemos no tempo ou no espaço, que mudemos o seu público ou o trovador que a enuncia, que a voltemos contra um novo alvo.

Os trovadores galego-portugueses certamente entreviam essa possibilidade de manipular os múltiplos sentidos de uma cantiga satírica, de utilizá-la como instrumento de muitas faces - algo como uma espada ou armadura que se presta a muitas cruzadas e que a cada instante é já nova armadura ou nova espada, pois que a simples mudança do cavaleiro que vai por trás dela ou da batalha que se tem em vista já a transmudou por completo.

5 Os três cancioneiros encontram-se atualmente impressos, contando com edições importantes das quais elegemos a de Carolina Michaëlis de Vasconcelos para o Cancioneiro de Ajuda (1904), a de Teófilo Braga para o Cancioneiro da Vaticana (1878), e a de Elza Pacheco Machado para o Cancioneiro da Biblioteca Nacional (1949). 
Para além disto, o mundo se transforma independentemente da vontade do cavaleiro, do poeta que conduz a sua cantiga-armadura. Em sua peregrinação por um mundo em permanente transformação, um verso se transfigura a cada instante, a cada leitura e a cada audição. Para compreender isto, é preciso perceber a leitura e a audição como práticas criadoras ${ }^{6}$. O mundo transfigura o poema porque se transfiguram os olhares e os ouvidos que para ele se voltam, e também porque este poema é inserido em novas práticas, é recriado mesmo a partir destas novas práticas ${ }^{7}$.

O encantador paradoxo da poesia está em que esta transmutação se opera sem que a forma sequer se altere. Enquanto uma narrativa que é transmitida por via oral sofre múltiplas interferências, interpolações, reorganizações do discurso ${ }^{8}$ - dada a própria natureza do discurso narrativo -, a poesia, mais ainda a cantiga, está aprisionada dentro de uma grade versificatória, de um ritmo, de um jogo combinatório de sonoridades. Não é possível alterar uma palavra, na sua dimensão material, sem que a estrutura poética desmorone. É isto o que assegura, aliás, a passagem de uma poesia através do tempo em toda a sua integridade material.

No entanto, este poema aprisionado em uma grade versificatória, esta cantiga encerrada em uma estrutura melódica, exercem espetacularmente toda a sua liberdade. Sem mudar uma única palavra, trazem à tona mil novos sentidos a cada novo contexto de enunciação. A grade de versos e ritmos não é para eles um túmulo, nem a estrutura melódica é para eles um cárcere. É antes um meio de libertação, que os permite incólumes atravessar todos os tempos. Já se disse que "um livro muda pelo fato de não mudar enquanto o mundo muda" (BOURDIEU; CHARTIER, 1985, p. 217-239). Ainda com mais propriedade podemos considerar isto para o poema, este gênero de discurso que, mesmo quando transmitido basicamente pela oralidade - meio transfigurador por natureza - conserva-se a si mesmo sendo já um "outro". A estrutura singular do discurso poético lhe dá uma imunidade material, ao mesmo tempo em que de fato não o aprisiona, sobretudo em virtude da natureza fluida da linguagem poética.

6 "para tal, uma noção parece ser útil, a noção de apropriação; porque permite pensar as diferenças na divisão, porque postula a invenção criadora no próprio cerne dos processos de recepção" (CHARTIER, 1990, p.136).

7 "as práticas que deles se apoderam são sempre criadoras de usos e representações que não são de forma alguma redutíveis à vontade dos produtores de discursos e de normas" (CHARTIER, 1990, p.136).

8 Isto é bem evidente nas narrativas dos "livros de linhagens" do mesmo período. Estas narrativas que circulavam por via oral foram registradas em momentos diferentes no Livro Velho, no Livro do Deão e no Livro de Linhagens do Conde D. Pedro. A cada passagem para um novo manuscrito, ou a cada inserção em novo livro genealógico, uma mesma narrativa original sofreu transformações significativas em sua forma-conteúdo. Tal deveria se verificar, ainda com mais intensidade, nas múltiplas exposições orais. 
Tudo isto nos conduz a um plano de trabalho, a um método de aproximação de nossas fontes. Será preciso considerar - além do emissor e dos múltiplos sentidos que ele pretende oferecer ao seu antecipado ouvinte (ou leitor) - "o texto, o objeto que lhe serve de suporte e a prática que dele se apodera" (CHARTIER, 1990, p.127). O texto: material que se move em um universo de significações; o suporte: ora o veículo oral, ora o manuscrito que aprisionou a cantiga; a prática que dela se apodera: esta que traz para o processo receptivo uma gama de ouvintes e leitores que o autor da cantiga não poderia ter previsto. A abordagem acima destacada pode ser utilizada para uma gama muito grande de cantigas satíricas do trovadorismo ibérico, que além de tudo constituem um material poético que se abre da maneira bastante significativa a um dialogismo latente. Ao tema que nos interessa neste momento, as tensões sociais e disputas de poder que se dão no contexto dos processos de centralização política que ocorrem tanto no reino de Portugal como no reino de Castela, prestam-se como materiais de análise inúmeras cantigas que trazem a nu toda uma série de oposições sociais. Para este artigo, contudo, escolheremos analisar uma única cantiga, no sentido de mostrar como um só poema trovadoresco dotado de riqueza dialógica já é suficiente para trazer à luz uma grande diversidade de tensões sociais e políticas, que vão se deslocando e se transfigurando na medida em que são redefinidas a emissão e a recepção do discurso poético em questão. Tomaremos para análise uma famosa cantiga medieval ibérica, hoje conhecida como "A lealdade do Bezerra":

"A lealdade da Bezerra pela Beira muito anda:

ben é que a nostra vendamos, pois que no-lo Papa manda.

Non ten Sueiro Bezerra que tort'é en vender Monsanto, ca diz que nunca Deus diss' a San Pedro mais de tanto: - Quen tu legares en terra erit ligatum in celo: poren diz ca non é torto de vender om'o castelo.

E poren diz que non fez torto o que vendeu Marialva, ca lhe diss' o arcebispo un vesso per que se salva: - Estote fortes in bello et pugnate cum serpente; poren diz que non é torto quen faz traiçon (e) mente.

o que vendeu Leirea muito ten que fez o dereito, ca fez mandado do Papa e confirmou-lh' o Esleito: 
- Super istud caput meum et super ista mea capa, dade o castelo ao Conde, pois vo-lo manda o Papa.

O que vendeu Faria pera remir seus pecados, se mais tivesse, mais daria; e disseron dous prelados: - Tu autem, Momine, Dimitte aquel que se confonde ben esmolou en sa vida quen deu Santaren ao Conde

Ofereceu Martim Diaz aa cruz, que os confonde, Covilhãa, e Pero Diaz Sortelha; e diss'o Conde:

- Centuplum accipiatis de mão do Padre Santo. Diz Fernan Diaz: - Ben m'est[e], por que oferi Monsanto.

Ofereceu Trancoso, ao Conde Roi Bezerro; falou enton Don Soeiro por sacar seu filho d'erro: - Non potest filia mea sine patre suo facere quidquam: salvos son os traedores, pois ben isopados ficam!

O que ofereceu Sintra fez come bon cavaleiro, e disso-lh'i o legado log' un vesso do Salteiro: - Sagitte potentis acute - e foi ben acordado: melhor é de seer traedor ca morrer escomungado.

E quando o Conde ao castelo chegou de Celorico, Pachequ' enton o cuitelo tirou; e disse-lh' un bispo: - Mitte gladium in vagina, con el non nos empeescas.

Diz Pacheco: - Alhur, Conde, peede u vos digan: Crescas!

Mal disse Don Airas Soga ùa velha noutro dia: disse-lhi Pero Soárez um vesso per clerizia:

- Non vetula bonbatricon scandit confusio ficum; non foi Soeiro Bezerra alcaide de Celorico.

Salvos son os traedores quantos os castelos deron; mostraram-lhi en escrito que foi ben quanto fezeron, super ignem eternum et ad unitatis open: salvo é quen trae castelo, a preito que o isopen!" 
A cantiga foi composta em torno de 1247. No exílio de Castela, um nobre português chamado Airas Peres Vuitoron ${ }^{9}$ discordava dos rumos políticos que Portugal havia tomado com a deposição do rei D. Sancho II. Aqui se dirige, com fina e afiada ironia, contra os alcaides da Beira que haviam entregado seus castelos ao Conde de Bolonha, mais tarde D. Afonso III de Portugal. A composição foi enunciada inúmeras vezes nos paços e casas senhoriais dos partidários e simpatizantes do rei deposto D. Sancho II, e seguramente contribuiu para o prestígio que Vuitoron, freqüentador de alguns destes paços por ocasião do seu exílio em Castela, alcançou em meados do século XIII.

O que se tem, portanto, é em primeira instância uma rede de tensões internobiliárquicas. $O$ autor está inserido dentro de um setor de nobres portugueses que se haviam exilado em Castela. Deste lugar ideológico, volta-se o autor contra todo um outro setor da nobreza que apoiara D. Afonso III na Guerra Civil de 1245.

Os nobres pertencentes a este último grupo, mormente os alcaides, haviam assumido conscientemente uma posição de rebeldia, à qual não foram constrangidos senão pelos interesses que os motivavam a acompanhar a nova configuração de poder. Afinal, "salvo de surpresa, não era possível tomar um castelo de pedra a não ser através dum cerco prolongado" (FOURQUIN, 1984, p.88). A rapidez com que o conde de Bolonha se assenhoreou do cinturão de castelos atesta a franca cooperação dos alcaides, sem qualquer resistência. A partir daí, "covardia", "traição" ou "rebeldia", tudo é uma questão de diversas leituras sociais de um mesmo acontecimento.

Toda a argumentação poética de Vuitoron está em mostrar que os alcaides traidores haviam rompido compromissos de fidelidade vassálica, e logo traído o próprio ideal cavaleiresco da época. Acusava-se assim os partidários de $\mathrm{D}$. Afonso III de um comportamento não condizente com o ideal de nobreza. Nesse ponto, portanto, o autor opera por uma contraposição entre modelos e contramodelos de vassalidade. Os contramodelos correspondem, naturalmente, a Soeiro Bezerra e aos demais alcaides traidores. Cada qual é referido em uma estrofe - ou indiretamente pela menção do castelo que foi entregue (Leria, Monsanto etc.), ou mesmo nominalmente (Martins Dias, Airas Soga).

Já o modelo ideal de nobreza, oculto na maior parte das estrofes mas pressentido por contraste, toma a forma de um personagem nas estrofes 9 e 10. Trata-se do Alcaide de Celorico, que mais tarde se cristalizaria no 
imaginário cavalheiresco ibérico como um modelo ideal de nobreza. Aqui vemo-lo se recusando ( $10^{\mathrm{a}}$ estrofe) a entregar seu castelo, em meio à torrente de traições vassálicas dos demais alcaides da Beira.

No último verso da $10^{\mathrm{a}}$ estrofe, a contraposição entre este modelo de cavaleiro e seus contramodelos torna-se ainda mais explícita ("Non foi Soeiro Bezerra Alcaide de Celorico"). No século seguinte, o Alcaide de Celorico irá reaparecer em uma narrativa que o enaltece como o máximo modelo de fidelidade e de cumprimento de compromissos feudo-vassálicos (LL 55Q6) ${ }^{10}$. Trata-se, no entanto, de um novo ocupante do posto, Martins Vasques da Cunha, que em 1282 incompatibiliza-se com o rei D. Dinis mas encontra uma maneira honrada de abandonar o castelo que o monarca não se apressava em receber de volta. Assim, o personagem que se tornaria lendário nos séculos seguintes, e que em "A Lealdade da Bezerra" já aparece como modelo de fidelidade, é composto na verdade de duas figuras históricas que ocuparam o mesmo posto em tempos distintos.

Voltando à atmosfera do século XIII, o que temos na cantiga é uma apropriação de modelos e contramodelos de nobreza para propósitos depreciativos. A confusão entre o Bezerra (sobrenome) e a Bezerra (animal simbolizando a covardia) logo no primeiro verso ("A lealdade da Bezerra pela Beira muito anda"), bem como entre a Beira (região de Portugal onde ocorreram as traições vassálicas) e a "beira" no sentido de "margem", é outros dos recursos utilizados pelo autor da cantiga para tratar pejorativamente seus adversários políticos.

Atacando diretamente os partidários de D. Afonso III, a cantiga também se volta indiretamente contra o novo rei de Portugal: é no fundo a sua própria legitimidade, a do novo ramo da dinastia de Borgonha, que aqui se questiona. Desta forma, a cantiga se torna aqui uma outra: o libelo de uma faç̧ão da nobreza contra o rei. Esse segundo sentido seria constantemente atualizado durante o governo centralizador de D. Afonso III: sempre que um nobre entoasse essa cantiga em Portugal, no fundo estaria como que questionando, por via indireta, a própria autoridade régia. O mesmo sentido the poderia ser emprestado no tempo de D. Dinis, onde o embate centralizador segue adiante de maneira mais acirrada.

10 LL é a abreviatura habitualmente utilizada para narrativas do Livro de Linhagens, genealogia portuguesa do século XIV que traz algumas narrativas contemporâneas à mesma época em que circulavam as cantigas trovadorescas do século XIII. Para o Livro do Deão, outra genealogia da época, utiliza-se LD; e para o Livro Velho, um livro de linhagens um pouco anterior, utiliza-se a abreviatura LV. 
Neste sentido de crítica contra o novo ramo dinástico de Portugal, a cantiga tornava-se, assim, um excelente "artefato cultural" a ser empunhado pela nobreza no seu embate contra o novo modelo de monarca centralizador que emergira daquela crise política. Mas é do "artefato" se prestar à livre manipulação. Mesmo os novos monarcas não seriam insensíveis à possibilidade de utilização em seu próprio benefício destas cantigas, tão enraizadas na psique coletiva.

Por paradoxal que pareça, a mesma cantiga poderia ser utilizada pelo monarca para favorecer o seu projeto centralizador. Afinal, em seu sentido primeiro ela desmerece um grupo de nobres que traíram o seu rei. Vinha então carregada de uma importante função ideológica: fixava normas de fidelidade vassálica que "para os reis confrontados com as revoltas dos nobres, se vieram a tornar em breve de uma importância decisiva" (MATTOSO, 1987, p.34). Ora, tanto os monarcas portugueses como Afonso X de Castela tiveram de se defrontar com insurreições da nobreza. D. Dinis, por exemplo, se debate contra a revolta do norte senhorial no final de seu reinado. Afonso X contra a rebeldia dos Laras e Haros, que se arrasta para os governos de seus sucessores ${ }^{11}$. Compreende-se, desta forma, os interesses da monarquia centralizadora em se apropriar do ideal de fidelidade vassálica. o "artefato" - a cantiga do exílio - amolda-se agora às mãos do mesmo rei que primordialmente o poeta pretendia condenar. É assim que, desde que entoada por um rei, a mesma cantiga, que antes falava de um poder usurpado ilegitimamente pelo monarca, pronuncia-se agora contra potenciais traidores deste mesmo rei. Os dois sentidos sobrepostos, e que podiam ser ressaltados conforme a conveniência, asseguram a sua circulação em ambientes opostos e em tempos distintos.

Mas a multiplicidade de sentidos não para por aí. Já o primeiro verso - e na verdade todas as estrofes - introduz uma outra ideia também central que é a crítica à interferência da Igreja em assuntos temporais: "A lealdade da Bezerra pela Beira muito anda: / bem é que a nostra vendamos, pois que no-lo Papa manda". Na guerra civil de 1245 , a Igreja fora uma das responsáveis diretas pela ascensão de D. Afonso III ao poder - já que, dando vazão a uma política de intervenção do poder eclesiástico no poder temporal

11 Diogo Lopes de Haro III, senhor de Biscaia, entra em revolta contra o rei de Castela já em 1254. Na geração seguinte, em 1287, Lopo Dias de Haro já aparece como apoiante do novo monarca Sancho IV; para no ano seguinte ser morto pelos oficiais do mesmo rei sob acusação de conluio contra o monarca de Castela (LL 9A14). Quanto à oposição entre os Laras e a monarquia centralizadora, esta só se resolve definitivamente em 1336, com a rendição de João Nunes de Lara III a Afonso XI (LD 18F9). Estas duas linhagens, rivais em diversos momentos mas que têm em comum a oposição ao centralismo monárquico, personificam em diversos conflitos os interesses senhoriais castelhanos. Para além deste embate contra as velhas e tradicionais linhagens, Afonso X defronta-se ainda com D. Henrique e o infante Sancho em dois momentos diversos. 
conforme determinações do Concílio de Lyon, o papa Inocêncio III nomeara o conde de Bolonha "curador de Portugal". Os traidores dos castelos, aliás, argumentavam precisamente que era preferível permanecer fiel à Igreja do que ao rei deposto, justificando sua traição por esse argumento que é ironizado na cantiga de Airas Peres Vuitoron. Na estrofe 8, o argumento é posto explicitamente na boca de um dos traidores ("melhor é ser traidor, que morrer excomungado").

Além disso, deve-se ressaltar que os alcaides traidores podiam voltar contra seus acusadores o próprio imaginário feudo-vassálico que contra eles era dirigido, mediante uma sutil manobra de pensamento que remetia à própria fundação de Portugal. ... Quando da constituição do reino, D. Afonso Henriques havia oferecido ao Papa homenagem lígia - hábil maneira de assegurar, com o beneplácito eclesiástico, a autonomia e a permanência do novo país recém desligado de Castela ${ }^{12}$. Esse vínculo de vassalidade estrategicamente constituído, que na prática sempre foi invocado ou ignorado pelos reis de Portugal conforme a ocasião pedia, foi naquele momento fundador da garantia de uma legitimação internacional do novo reino. Ora, por essa linha de pensamento, o Papa era o "senhor lígio" de Portugal, pelo que todos do reino deveriam à Igreja Romana uma fidelidade mesmo maior que a devida ao monarca. Assim sendo, aceitar a determinação do senhor lígio (o papa) ao nomear um novo rei não era de modo nenhum trair o código feudo-vassálico. Pelo contrário, era cumpri-lo à risca no âmbito mais amplo da homenagem lígia.

Tal argumento era um instrumento eficaz para escapar à armadilha que sempre envolve as traições feudais: afinal, o vassalo que se revolta contra o rei, mesmo que este seja um monarca enfraquecido politicamente, sempre incorre no risco de contaminar com seu exemplo a rede de vassalidade abaixo de si, atraindo contra si revoltas de seus próprios vassalos. Esta situação tão concreta pesa mais no nobre que a angústia moral de trair a fé jurada ${ }^{13}$. Por isso que, antes de trair os seus compromissos de fidelidade, um nobre feudal sempre se ancora em novas alianças e laços de reciprocidade, para baixo e para cima, o que foi o caso dos alcaides ao se enredarem na nova configuração de poder trazida por Afonso III. Ou, ainda, é eficaz invocar um compromisso feudal superior, que torne justificável o rompimento do segundo. Este o papel do argumento da "homenagem lígia" devida ao Papa, empunhado pelos alcaides

12 Afonso Henriques presta homenagem vassálica ao papa Inocêncio II em 1143, e é reconhecido como rei de Portugal pelo papa Alexandre III em 1179 (bula Manifestis probatum). Expressão de sua estratégica declaração de vassalagem encontra-se em Documentos Medievais Portugueses. Documentos régios (1958-1961, doc.202).

13 Fawtier demonstrou, estudando o caso francês, que este mecanismo de pressões e contrapressões está na base da permanência das monarquias feudais, mesmo nos momentos em que estas se viram mais enfraquecidas, como durante o reinado de Felipe I (FAWTIER, 1942). 
traidores e ridicularizado por Vuitoron. $\mathrm{O}$ argumento está implícito em alguns versos, como os das $1^{\mathrm{a}}$ e $4^{\mathrm{a}}$ estrofes ("pois que no-lo Papa manda" e "dade o castelo ao Conde, pois vo-lo manda o Papa"). Sem querer, o autor não pode evitar o diálogo com seus alvos aparentemente tão passivos, o que remete mais uma vez à questão já levantada de que, mesmo na poesia de estrutura monológica, emerge por vezes um diálogo de contraposição onde também os alvos têm sua voz, e acabam participando de uma espécie de "tenção encoberta".

o que foi visto até aqui mostra como o imaginário cavaleiresco podia ser manipulado por um lado ou outro - tornando-se também ele uma arena para ideias e objetivos antagônicos. Dito de outra forma, os próprios alvos de cantigas como "A Lealdade da Bezerra" podiam retorcer toda a base de uma argumentação que se voltava contra eles. Mas, de qualquer forma, Vuitoron não fazia por menos. Seguia alvejando tanto os partidários de D. Afonso III como a própria Igreja — uma vez que esta vinha ideologicamente em favor dos traidores ao sancionar a traição vassálica em nome de uma fidelidade maior devida ao papa e à cristandade.

Digno de nota é o criativo artifício que faz parte da própria estrutura versificatória da cantiga. Os terceiros versos de cada estrofe estão escritos em latim, língua que remete imediatamente a textos eclesiásticos. $O$ autor, assim, ironiza a Igreja a partir de seus recursos discursivos próprios. Mais ainda: ao incluir ironicamente as citações em latim, o autor está emitindo simultaneamente diversas mensagens - dá-nos mostra de sua própria erudição como um nobre letrado, questiona o monopólio da Igreja quanto ao sagrado e, por fim, afirma-se perante as autoridades eclesiásticas que pretende questionar. O hábil recurso cria, de certo modo, três "registros" dentro da cantiga. Um deles é o do discurso direto em latim, por vezes um "latim macarrônico". Neste registro, o autor isola a argumentação da alta hierarquia eclesiástica a favor dos atos de traição. Empresta-lhe uma entonação a um só tempo hipócrita e pomposa. Os emissores eclesiásticos vão se alternando a cada estrofe - o Papa, o Arcebispo, um Bispo, dois prelados - como que a abarcar a totalidade da cúpula eclesiástica.

A degradação do latim para uma tonalidade caricata, em algumas estrofes, assoma-se como mais uma nota depreciativa, lançando dúvidas sobre a erudição pomposa dos eclesiásticos. Manuel Rodrigues Lapa interpreta a expressão per clarizia (v. 36) como remetendo a "em latim macarrônico" (LAPA, 1981, p.132). Isto favorece nossas suposições, já que a estrofe ficaria assim:

“disse-lhe Pero Soárez um versículo em 'latim macarrônico':

- Non vetula bonbatricon scandit confusio ficum;

non foi Soeiro Bezerra Alcaide de Celorico" 
Outro registro é o do discurso indireto que se apresenta na argumentação falaciosa dos traidores vassálicos. Aqui, ainda estamos no idioma galego-português, mas invocando expressões caras ao vocabulário feudo-vassálico ("O que ofereceu Sintra, fez como bom cavaleiro", v. 27) ou ao universo devocional ("o que vendeu Faria para remir os seus pecados, se mais tivesse, mais daria", v. 15). Isso empresta ao discurso construído para os alcaides traidores uma entonação risível, com o vocabulário vassálico sendo deslocado para justificar precisamente a traição vassálica e o linguajar devocional para "justificar o pecado". Estes dois discursos, o da contraditória indignidade dos alcaides e o da pomposa hipocrisia eclesiástica, andam de mãos dadas no decorrer da cantiga, já que o primeiro cita o segundo em sua própria defesa e justificativa. Acima destes dois registros parodiados, está o do autor, que se oculta na maior parte do poema como se fosse um narrador neutro, mas sem esconder o seu sarcasmo.

Devemos imaginar o efeito irresistivelmente cômico que a cantiga devia favorecer se acompanhada das entonações e gestos adequados: a falsa humildade dos traidores e a pompa dos eclesiásticos que a eles se aliavam. Cada registro - acrescido destas componentes de pronúncia e de espetáculo - introduz não apenas um vocabulário e uma linguagem próprios, como também a sua fala e o seu gesto particulares. Tudo isto nos favorece a percepção de que a linguagem poética de uma cantiga também pode conter uma variedade de "registros internos". Com habilidade, Airas Peres Vuitoron consegue pô-los a dialogar, fazer com que os registros dos traidores e dos eclesiásticos estabeleçam alianças espúrias, acentuadas pela comicidade; por fim, faz com que estes dois registros entrem em contraposição dialógica com o próprio imaginário cavaleiresco. Busca-se, assim, contrapor os alvos e a plateia, aqui conclamada a enxergar nos registros alvejados contramodelos e figuras caricatas.

Ainda sobre a utilização do registro em latim, chamamos atenção para a $7^{\mathrm{a}}$ estrofe:

"falou então Don Soeiro para isentar seu filho do erro:

- Non potest filia mea sine patre suo facere quidquam:

salvos são os traidores, pois bem isopados ficam!"

Há uma ligeira divergência entre as versões do Cancioneiro da Biblioteca Nacional (CBN) e do Cancioneiro da Vaticana (CV), que são versões possivelmente renascentistas do já mencionado Livro de Cantigas do século XIV (o CBN, por exemplo, deve a sua preservação ao colecionador quinhen- 
tista Ângelo Colloci, tendo sido por muito tempo conhecido como Cancioneiro Colocci-Brancuti). A versão aqui transcrita é a do CBN, que é praticamente idêntica à do $\mathrm{CV}$, com a exceção de que no último aparece no verso em latim a expressão fillius meus no lugar de filia mea. É de supor que, no último cancioneiro, um escriba desatento tenha corrigido a expressão. Apagou, assim, a formidável ironia de Vuitoron. Como observa M. R. Lapa, "usando muito de propósito a forma feminina, quer Vuitoron significar e flagelar a cobardia mulherenga do filho (= filha) de Soeiro Bezerra. É uma frechada de mestre." (LAPA, 1981, p.131). Felizmente, o escriba do CBN foi mais hábil em compreender a ironia do trovador e não se permitiu fazer qualquer alteração. Isso nos coloca mais uma vez diante da importância de perceber a entonação do verso, tal como ele a teria reintroduzido no contexto do espetáculo. Por vezes, somente resgatando a oralidade e o gesto é que podemos escolher a versão mais pertinente ou valorizar o detalhe significativo.

Posto tudo isto, um dos objetivos maiores do poeta era o de comentar uma questão que estava na ordem do dia: o embate entre o poder temporal e o poder eclesiástico. Ora, o embate entre os dois poderes, essa era uma questão que afetava tanto os reis de Portugal como Afonso X de Castela. Particularmente o Rei Sábio se vira diretamente envolvido em confrontos contra o papa. Isto além dos conflitos entre o projeto centralizador e a autonomia da Igreja local, também corriqueiros no Portugal de D. Afonso III e D. Dinis (MATTOSO, 1985, p.158-162). Não é de estranhar que Afonso X tenha contribuído para pôr a correr cantigas como "A Lealdade da Bezerra", emprestando o ambiente do seu Paço à sua livre expressão. Queria alvejar agora a interferência eclesiástica nos seus domínios, pelo que um novo sentido se sobrepunha aos demais. É assim que a cantiga é encoberta também por uma rede de tensões interfuncionais, opondo o circuito bellatore / temporal ao circuito oratore / eclesiástico. À rede de tensões internobiliárquicas e ao embate entre rei e nobreza vem se juntar o embate entre as duas ordens superiores, aqui passível de ser reapropriado pelos monarcas para as suas próprias estratégias políticas.

Completa-se, assim, um quadro da multiplicidade de sentidos que uma mesma cantiga pode assumir, consoante o lugar de onde é proferida, quem a profere, e a quem e contra quem ela se dirige. Talvez ainda possamos acrescentar que, na voz de um jogral não-aristocrata, a mesma cantiga poderia ainda se converter em uma crítica mordaz à nobreza como um todo, incapaz de conservar no plano prático os seus próprios ideais cavaleirescos. Era precisamente essa multiplicidade de sentidos que empurrava uma cantiga como a que vimos para todos os tempos e lados: ela era constantemente atualizada pelos problemas que tocava nos seus vários extratos de sentido. Assim, atravessava as filtragens locais e a filtragem de um século sobre o 
outro. Um sentido novo ou reavivado trazia a reboque todos os demais. Por sua pluralidade interna, a cantiga atravessava incólume todos os tempos e fronteiras, como uma armadura que enfrentasse muitas cruzadas e que ocultasse a cada instante um novo guerreiro.

\section{REFERÊNCIAS}

1. Fontes Medievais

Cancioneiro da Ajuda. ed. Carolina Michaëlis de Vasconcelos. Halle: 1904. 2 v.

Cancioneiro da Biblioteca Nacional. Elza Paxeco Machado e José Pedro Machado (org.). Lisboa: Ocidente, 1949.

Cancioneiro Portuguez da Vaticana. ed. Teófilo Braga. Lisboa: 1878.

Documentos Medievais Portugueses. Documentos régios, v. I. tomo I e II. Lisboa: Academia Portuguesa de História, 1958-1961.

Livro de Linhagens do Conde D. Pedro. ed. José Mattoso. "Nova Série” dos Portugaliae Monumenta Historica. Lisboa: A.C.L., 1980.

Livros Velhos de Linhagens. ed. José Mattoso e Joseph Piel. "Nova Série” 2 Portugaliae Monumenta Historica. Lisboa: Academia de Ciências, 1980.

2. Bibliografia

BOURDIEU, P. e CHARTIER, R. La lecture, una pratique culturelle. In ? CHARTIER, R. (org.). Pratiques de la lecture, Marselha: Rivages, 1985.

CHARTIER, Roger. Textos, Impressos, Leituras. In: . A História Cultural. Lisboa: Difel, 1990. FOUCAULT, Michel. Microfisica do Poder. Rio de Janeiro: Graal, 1979.

FAWTIER, R. Les Capétiens et la France. Paris: Presses Universitaires de France, 1942

FOURQUIN, G. Senhorio e feudalidade na Idade Média. Lisboa: Edições 70, 1984.

LAPA, Manuel Rodrigues. Lições de Literatura Portuguesa. Coimbra: 1981. 
BARROS, J. D'A. A PoEsia como arma de combate: um estudo Sobre a REAPRopriação de SENTIDos...

. Cantigas D'escarnho e de mal dizer. Lisboa: Galáxia, 1975.

MATTOSO, José. Fragmentos de uma Composição Medieval. Lisboa: Estampa, 1987.

Identificação de um país - ensaio sobre as origens de Portugal 1096-1325. Lisboa:

Estampa, 1985, 2 vol.

NIETZSCHE, Friedrich. A Genealogia da Moral. São Paulo: Hemus, 1981.

ZUMTHOR, Paul. A Letra e a Voz. São Paulo: Companhia das Letras, 1994.

Submetido em: 24/07/2013

Aceito em: 20/06/2014 